\title{
Herpes simplex virus type 1 persistence and latency in cultured rabbit corneal epithelial cells, keratocytes, and endothelial cells
}

\author{
S D COOK $^{12}$ AND S M BROWN
}

From the 'Tennent Institute of Ophthalmology and the ${ }^{2}$ Medical Research Council Virology Unit, University of Glasgow, Church Street, Glasgow G11 5JR

SUMmaRY Cell cultures of rabbit corneal epithelium, keratocytes, and endothelium were used to determine the lytic cycle of herpes simplex virus type 1 . Viral growth was fastest in epithelial cells. A novel HSV-1 in-vitro latency system was established in the three distinct cell types. Cell cultures were inoculated at low multiplicities of infection with HSV-1. Temperature manipulation alone was used to induce and reactivate latent HSV-1 infections. The presence of cellular stress proteins was demonstrated at supraoptimal temperatures. All cell types were capable of maintaining latent viral infections under these conditions. Viral persistence was present in $20 \%$ of epithelial cell cultures at supraoptimal temperatures, but not in keratocyte cultures or endothelial cell cultures.

Herpes simplex virus (HSV) can react with host cells in vivo or in vitro to produce cytocidal infection, persistent infection, transformation of cells, or latent infection. Latent HSV appears to reside preferentially in the neurones of the dorsal root ganglia and the virus has been isolated from human ganglion explants ${ }^{12}$ and animal ganglion explants. ${ }^{3-5}$

The possibility that peripheral non-neural sites may support a persistent or latent HSV infection has been suggested by the isolation of virus from the clinically normal skin of latently infected mice, ${ }^{6}$ by the isolation of virus from guinea-pig skin when virus was not found in the corresponding ganglia, ${ }^{7}$ and by the isolation of virus from the footpad of mice. ${ }^{8} \mathrm{HSV}$ has also been isolated from ocular explants after long periods of cocultivation. ${ }^{9}$

Latent virus can reactivate in vivo to cause viral shedding with no evidence of clinical disease in rabbit eyes, ${ }^{10}$ or it can produce recrudescent epithelial disease in mice. "In man ocular herpes simplex virus infection may affect the cornea and cause significant morbidity. Recurrent disease can cause progressive opacification and scarring of the cornea resulting in visual impairment and blindress. The disease is initially superficial, affecting epithelial cells. ${ }^{12}$ However, severe disease can involve the deeper stromal

Correspondence to S D Cook FRCS Ed, Tennent Institute of Ophthalmology, Western Infirmary, Glasgow G11 6NT. layers, affecting the keratocyes. ${ }^{13}$ Corneal endothelial cell involvement has also been demonstrated. ${ }^{14}$

Previous studies on fixed human corneae have demonstrated viral particles by electron microscopy ${ }^{1516}$ or the presence of viral antigens by immunofluorescence. ${ }^{17}$ However, recovery of infectious virus from deeper corneal layers during quiescent periods has been largely unsuccessful. Recent reports ${ }^{1819}$ have shown that virus was recovered from six out of nine corneae removed in the course of treatment for chronic stromal keratitis. Virus was isolated from the explanted corneae after five to 11 days in culture.

Three possibilities exist: ${ }^{19}$ virus is truly latent in corneal cells; virus persists within corneal tissue as a chronic low grade infection; or, prior to explantation of the cornea, the virus is transported to corneal cells from another source, namely the trigeminal ganglion.

In-vitro models of latency have been used in an attempt to elucidate the mechanisms of HSV latency. A number of cell systems have been utilised, including HEL fibroblast cells, ${ }^{20}$ rat fetal neurones, ${ }^{21}$ human fetal neurones, ${ }^{22}$ and transformed neuroblastoma cells. ${ }^{23} \mathrm{~A}$ latent viral state can be induced in infected cells by antiviral agents with ${ }^{24}$ or without, ${ }^{20}$ interferon and maintained by temperature elevation. ${ }^{25} \mathrm{~A}$ raised temperature alone has been shown to induce a latent viral state in HEL fibroblast cells in vitro. ${ }^{26}$ Temperature elevation induces the production of 
cellular stress proteins. ${ }^{27}$ The synthesis of these proteins can also be induced by HSV itself, though the presence of the proteins is transient in a lytic viral infection. ${ }^{28}$ The induction of cellular stress proteins by virus may have a role in the induction and maintenance of HSV latency. The factors controlling viral latency are unknown. Reactivation of infectious virus can be achieved in vitro by manipulation of the physical or chemical environment and by viral superinfection. ${ }^{24} 29$

The cornea contains three different cell types: epithelial cells, which replicate throughout life; keratocytes, which tend to be stable but have the potential for replication; and endothelial cells, which do not divide in vivo. ${ }^{3031}$ The aims of the present study were to determine whether the three rabbit corneal cell types could support lytic HSV-1 infection; whether these cells were capable of supporting latent HSV-1 infection; and whether there was a difference in the ability of the epithelial cells, keratocytes, and endothelial cells to support latent HSV-1 infection. It seemed pertinent to develop an in vitro latency system using cells in which the virus is known to occur in vivo, as a first step towards understanding the nature of the virus cell relationship in herpetic keratitis.

\section{Material and methods}

GROWTH OF VIRUSES

Virus stocks were grown and titrated in baby hamster kidney cells (BHK21C13) cultured in Eagle's medium (Glasgow modification) plus $10 \%(\mathrm{v} / \mathrm{v})$ calf serum (EC10). The virus strain used was HSV-1 Glasgow $17 .^{32}$

\section{CELLS}

Rabbit corneal cells were prepared by the method of Stocker et al. ${ }^{33}$ The corneae of New Zealand white rabbits (Hyline Rabbit Farms) were prepared by microdissection. Primary cultures of endothelial cells were obtained by separating Descemet's membrane from the stroma. The membrane was placed in tissue culture flasks (Nunclon $25 \mathrm{~cm}^{2}$ ) in growth medium which allowed the endothelial cells to migrate and proliferate. Epithelial cells were separated from the stroma by dissection and grown in flasks separately from the keratocytes, which migrated slowly from within the stroma before proliferating. Secondary cultures were obtained by splitting confluent primary cultures $1: 2$ with trypsin/versene. The medium found to give optimal growth of the three cell types was as follows: epithelial cells, Eagle's medium (Glasgow modification) plus $10 \%$ (v/v) fetal calf serum; keratocytes and endothelial cells, $20 \mathrm{mM}$ Hepes buffered Dulbecco's medium plus $10(\mathrm{v} / \mathrm{v})$ fetal calf serum, supplemented with $1 \%(\mathrm{v} / \mathrm{v})$ L-glutamine. Cultures were grown at $37^{\circ} \mathrm{C}$.

ONE-STEP GROWTH EXPERIMENTS

Confluent $35 \mathrm{~mm}$ plates of BHK $21 \mathrm{C} 13$ cells $\left(10^{\mathrm{s}}\right.$ cells), corneal epithelial cells $\left(10^{5}\right.$ cells $)$, keratocytes $\left(10^{5}\right.$ cells $)$, and endothelial cells $\left(5 \times 10^{4}\right)$ cells were infected with HSV-1 Glasgow 17 strain at a multiplicity of infection (MOI) of 10 plaque-forming units (PFU)/cell. After absorption for 1 hour at $37^{\circ} \mathrm{C}$ the cultures were washed twice in phosphate buffered saline (PBS) plus 5\% (v/v) calf serum (PBSC5) and overlaid with EC10. At various time intervals between 0 and 24 hours the infected cells were harvested and virus released by sonication. Samples were stored at $-70^{\circ} \mathrm{C}$ and virus titres measured by plaque assay on BHK $21 \mathrm{C} 13$ cells.

\section{NON-PRODUCTIVE INFECTIONS IN CORNEAL}

CELLS

Twenty-four confluent cultures of each cell type were grown in $25 \mathrm{~cm}^{2}$ flasks (approximately $10^{6}$ cells/flask) at $37^{\circ} \mathrm{C}$. The cells ranged from pass nos. 5-8 (epithelium); pass nos. 12 (keratocytes); or pass nos. 5-8 (endothelium). Cultures were maintained at $41.5^{\circ} \mathrm{C}$ for 24 hours prior to HSV-1 infection.

Eight flasks of each of the three corneal cell types were inoculated at MOIs of $0 \cdot 01,0 \cdot 1$, and $1 \cdot 0$ PFU/cell in $100 \mu \mathrm{l}$ of medium. Virus was absorbed for 45 minutes at $41 \cdot 5^{\circ} \mathrm{C}$. The cultures were then overlaid with the appropriate medium, which was changed every third day.

The presence of infectious virus was determined by two methods: (1) observation of viral plaque on the corneal cell cultures; (2) assay of $0.5 \mathrm{ml}$ corneal cell culture supernatant on BHK $21 \mathrm{C} 13$ cells. The assays were performed daily for two days after inoculation and then every third day, when the medium was changed.

At weekly intervals after inoculation two cell cultures at each MOI and of each cell type were transferred to $37^{\circ} \mathrm{C}$ The medium was supplemented with $5 \%(\mathrm{v} / \mathrm{v})$ human serum (HS) for the first five days at $37^{\circ} \mathrm{C}$. Human serum was added to neutralise any residual extracellular virus.

PREPARATION OF CORNEAL CELL PROTEIN GELS Radiolabelling of cells. Growth medium was removed from confluent $35 \mathrm{~mm}$ plates of epithelial and keratocyte cells and the cellular monolayers washed twice with PBS. Methionine-free Eagle's medium plus $2 \%(\mathrm{v} / \mathrm{v})$ calf serum was added. After 4 hours $10 \mu \mathrm{Ci}$ of ${ }^{35} \mathrm{~S}$ methionine was added to each culture for a further two hours. Control cultures infected with HSV at an MOI of $20 \mathrm{PFU} /$ cell were labelled with ${ }^{35} \mathrm{~S}$ methionine for 24 hours. After 
incubation, labelling medium was removed, monolayers were washed with ice cold PBS and cells disrupted in electrophoresis sample buffer.

Polyacrylamide gel electrophoresis. Radiolabelled samples were analysed by sodium dodecyl sulphate (SDS)-plyacrylamide gel electrophoresis using $7 \cdot 5 \%$ gels.

Gels were dried and autoradiographs prepared..$^{34}$

\section{Results}

CHARACTERISATION OF CORNEAL EPITHELIAL, KERATOCYTE, AND ENDOTHELIAL CELLS

The purity of the three distinct corneal cell types was established by indirect immunofluorescence with antibodies against fibronectin which identified the fibroblast-like keratocyte cells ${ }^{35}$ and endothelial cells; ${ }^{36}$ and by indirect innumofluorescence with antibodies against keratin which identified epithelial cells. ${ }^{37}$ Additional electron microscopy studies demonstrated distinct morphological characteristics of the three cell types, which permitted identification (manuscript in preparation).

ONE-STEP GROWTH KINETICS OF HSV-1 IN THREE CORNEAL CELL TYPES

To determine whether the three corneal cell types could support normal HSV-1 lytic growth, singlecycle growth experiments were carried out in epithelial cells, keratocytes, and endothelial cells with BHK $21 \mathrm{C} 13$ cells as control cultures. The experiment was done in duplicate, and the results are presented in Fig. 1 (a-d).

The results show that HSV-1 Glasgow strain 17 could replicate efficiently in the three corneal cell types. Distinct differences were observed. The curve for viral growth in BHK $21 \mathrm{C} 13$ cells characteristically showed a four-hour eclipse phase, a plateau of virus production within 24 hours, and a viral yield of around 100 PFU per cell (Fig. la). The viral growth curve in epithelial cells was similar, but the eclipse phase was slightly prolonged to six hours (Fig. 1b) Virus growth in keratocyte and endothelial cells showed a markedly prolonged eclipse phase of eight hours. The rate of growth was slower in both keratocytes and endothelial cells. Both curves were still in the logarithmic phase at 24 hours, suggesting that virus production had not reached a maximum by that time (Fig. 1c and d).

\section{NON-PRODUCTIVE INFECTIONS IN CORNEAL}

CELLS.

It has been suggested that the cornea may be a site of latent/persistent HSV infection. ${ }^{19}$ One way of determining which, if any, of the corneal cell types are capable of harbouring HSV in a non-infectious form is to induce conditions under which corneal cells are either unable to support, or able to suppress, virus replication. This was achieved by infecting the three types of corneal cells with $\mathrm{HSV}-1$ at various low multiplicities of infection at $41.5^{\circ} \mathrm{C}$. Supraoptimal temperatures are known to induce the production of heat shock polypeptides. ${ }^{262838}$ The cultures at $41 \cdot 5^{\circ} \mathrm{C}$ were monitored for infectious virus for up to 28 days after inoculation. At weekly time intervals during the 28 days cultures were transferred to $37^{\circ} \mathrm{C}$ and monitored for the shedding of infectious virus. Two assay methods (see 'Materials and Methods') were used to determine the presence of infectious virus. There was $87 \%, 79 \%$, and $77 \%$ correlation between the two assay methods in the epithelial, keratocyte, and endothelial cells respectively. The results presented are from the corneal cell culture supernatant assay on BHK $21 \mathrm{C} 13$ cells.

At the start of the experiment there were 24 cultures of each cell type. Cells were able to divide at $41.5^{\circ} \mathrm{C}$, so when cells became overconfluent, the cultures were split $1: 2$. The progeny cultures continued in the experiment at $41.5^{\circ} \mathrm{C}$, increasing the original number of cultures (Table 1 , a-c, column 1)

Infectious virus was detectable in all cultures on the first day after inoculation and in most cultures on the second day after inoculation (data not shown). A focal cytopathic effect, observed by rounding of cells, was seen to some extent in all cultures after HSV-1 infection. At higher MOIs ( $0 \cdot 1$ and $1 \cdot 0$ PFU/cell) cell death could be overwhelming by the seventh day, leaving no surviving cells. This was marked in keratocyte and endothelial cells, but was less noticeable in epithelial cells, where a small number of surviving cells were able to divide and re-form confluent monolayers. An anomalous finding was cell death in keratocyte cultures $3 \mathrm{~A}, 3 \mathrm{~B}, 4 \mathrm{~A}$, and $4 \mathrm{~B}$. Their parent cultures 3 and 4 , inoculated at the lowest MOI $(0.01$ PFU/cell) were subcultured on day 13 . On day 14 the progeny cultures were transferred to $37^{\circ} \mathrm{C}$ and medium was replaced by medium supplemented with $5 \%$ human serum. The cells had not settled on to the culture flasks by day 14 and were removed with the medium. Other keratocyte cultures $5 \mathrm{~A}-8 \mathrm{~B}$, subcultured on day 13 but left undisturbed at $41.5^{\circ} \mathrm{C}$ until day 16 , settled and ultimately became confluent (Table 1, a-c, column 2).

Persistent infection, defined as the presence of infectious virus in the supernatant medium at $41.5^{\circ} \mathrm{C}$, after the immediate period after infection, was detected in one epithelial cell culture infected at $0 \cdot 01$ PFU/cell and four epithelial cell cultures infected at $0 \cdot 1 \mathrm{PFU} / \mathrm{cell}$. The infection appeared to be partially suppressed in that it did not succeed in destroying cellular monolayers until cells were transferred to $37^{\circ} \mathrm{C}$. No infectious virus was detected in surviving 


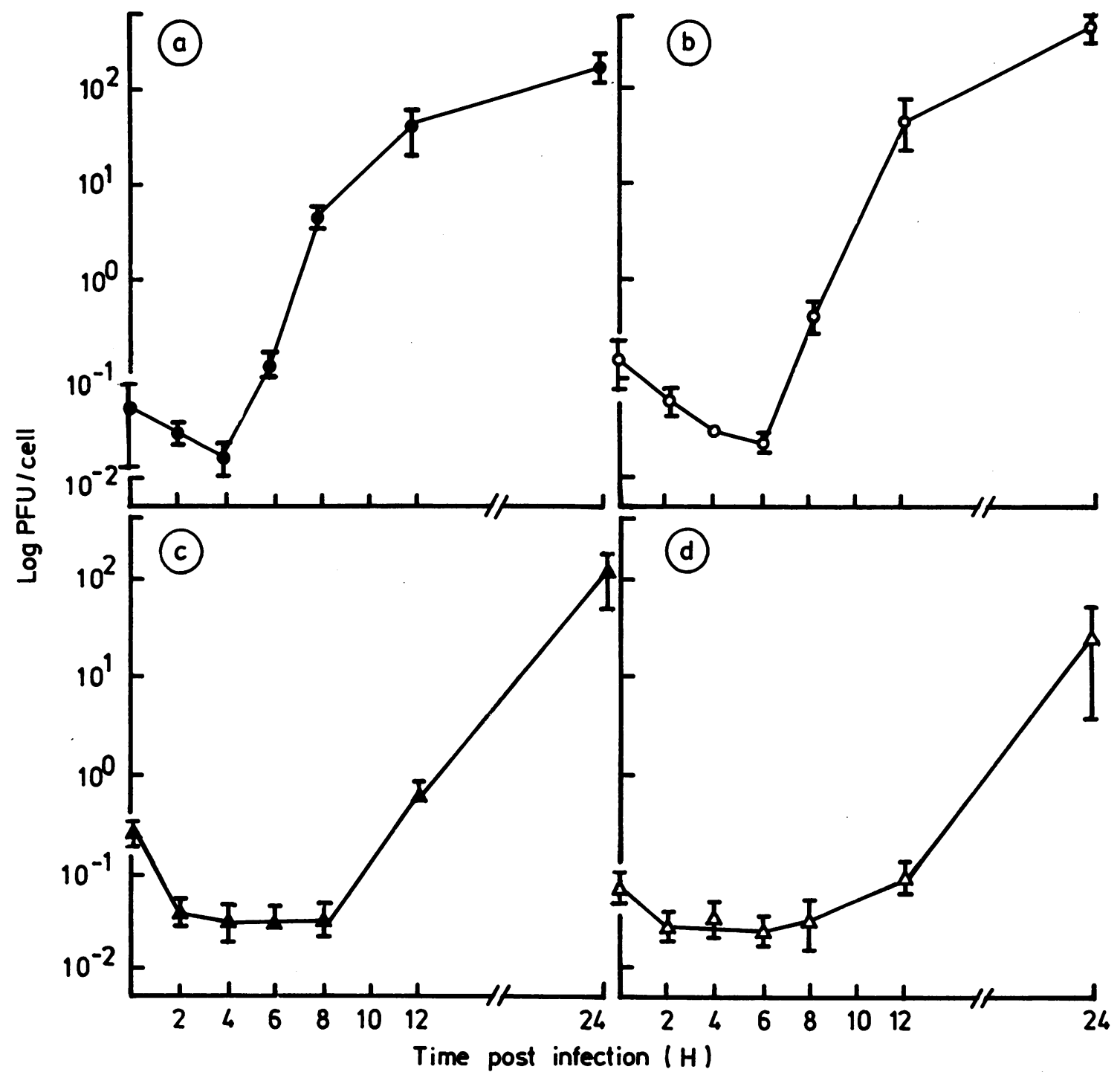

Fig. 1 One-step growth curves of HSV-1, Glasgow 17 strain in (a) BHK 21 C13 cells, (b) epithelial cells, (c) keratocyte cells, and (d) endothelial cells. Cells were infected at an MOI of $10 \mathrm{PFU} / \mathrm{cell}$. After absorption for 1 hour at $37^{\circ} \mathrm{C}$ the monolayers were washed twice with PBS C5, overlaid with EC10, and incubated at $37^{\circ} \mathrm{C}$ (see 'Material and methods'). Cultures were harvested at the times indicated and the virus titre measured by plaque assay on BHK21 C13 cells.

keratocyte and endothelial cell cultures maintained at $41 \cdot 5^{\circ} \mathrm{C}$ for up to 28 days after infection (Table $1 \mathrm{a}-\mathrm{c}$, column 4).

Latent infection was defined as absence of infectious virus in the supernatant medium at $41.5^{\circ} \mathrm{C}$, but detectable infectious virus in the supernatant medium after transfer to $37^{\circ} \mathrm{C}$. All cell types proved capable of releasing infectious HSV after human serum was removed at $37^{\circ} \mathrm{C}$ (Table 1 , a-c, column 5).
By day 40 after infection all surviving epithelial cells had released infectious virus, but five keratocyte and three endothelial cell cultures at $37^{\circ} \mathrm{C}$ had failed to release virus up to 20 days after removal of human serum. The eight cultures that failed to release infectious virus at $37^{\circ} \mathrm{C}$ were defined as reactivation failures (Table 1a-c, column 6). The release of infectious virus was quicker from epithelial cells and endothelial cells than from keratocytes after human serum was removed (Table 1a-c, column 7). 
Table 1a Course of non-productive infections in corneal cells: epithelium

\begin{tabular}{|c|c|c|c|c|c|c|}
\hline $\begin{array}{l}\text { Culture } \\
\text { number }\end{array}$ & $\begin{array}{l}\text { Culture } \\
\text { death }\end{array}$ & $\begin{array}{l}\text { No. of } \\
\text { days at } \\
41.5^{\circ} \mathrm{C}\end{array}$ & $\begin{array}{l}\text { Persistent } \\
\text { infection }\end{array}$ & $\begin{array}{l}\text { Latent } \\
\text { infection }\end{array}$ & $\begin{array}{l}\text { Reactiva- } \\
\text { tion failure }\end{array}$ & $\begin{array}{l}\text { Time of viru } \\
\text { release after } \\
\mathrm{HS} \text { removal } \\
\text { at } 37^{\circ} \mathrm{C} \\
\text { (days) }\end{array}$ \\
\hline $1^{*}$ & & 7 & & + & & 3 \\
\hline 2 & & 7 & & + & & 3 \\
\hline 3 & & 14 & & + & & 2 \\
\hline 4 & & 14 & & + & & 2 \\
\hline 5 & & 21 & & + & & 6 \\
\hline 6 & & 21 & & + & & 9 \\
\hline 7 & & 28 & + & & & \\
\hline 8 & & 28 & & + & & $2>$ \\
\hline $9 \mathrm{~A}+\S$ & & 7 & & + & & 3 \\
\hline $9 B$ & & 7 & & + & & 3 \\
\hline 10 & & 7 & & + & & 3 \\
\hline 11 & & 14 & + & & & \\
\hline 12 & & 14 & + & & & \\
\hline 13 & & 21 & & + & & 3 \\
\hline 14 & & 21 & + & & & \\
\hline 15 & & 28 & + & & & \\
\hline 16 & & 28 & & + & & 2 \\
\hline $17 \ddagger$ & $\mathrm{C}<$ & 7 & & & & \\
\hline 18 & & 7 & & + & & 3 \\
\hline 19 & & 14 & & + & & 4 \\
\hline 20 & & 14 & & + & & $4>$ \\
\hline 21 & & 21 & & + & & 9 \\
\hline 22 & & 21 & & + & & 3 \\
\hline 23 & & 28 & & + & & 2 \\
\hline 24 & & 28 & & + & & 2 \\
\hline
\end{tabular}

See footnote to Table 1c.

\section{CELLULAR STRESS PROTEINS}

As stated above, supraoptimal temperatures induce the synthesis of cellular stress proteins. Other agents including disulfiram, ${ }^{39}$ transition series metals, and sulphydryl reagents induce the synthesis of cellular stress proteins. ${ }^{38}$ Fig. 2 shows the effect of temperature elevation on protein synthesis in rabbit corneal epithelial cells and keratocytes. Disulfiram $0.3 \mu \mathrm{M}$ has been added to the cell growth medium at $37^{\circ} \mathrm{C}$ to obtain radiolabelled stress protein markers. In mock infected keratocytes and epithelial cells, incubated at $41.5^{\circ} \mathrm{C}$, there was increased synthesis of proteins with approximate molecular weights of 90000,75000 , and 43000 . Novel proteins with approximate molecular weights $70000,63000,53000$ and 45000 , also appeared to have been synthesised.

Many characteristic herpes simplex virus proteins were detected after 24 hours in both keratocyte and epithelial cells infected at $20 \mathrm{PFU} /$ cell and maintained at $37^{\circ} \mathrm{C}$; however, these were absent at $41.5^{\circ} \mathrm{C}$. The herpes simplex virus infected cells at $41.5^{\circ} \mathrm{C}$ had similar protein profiles to those of the mock infected cells at $41 \cdot 5^{\circ} \mathrm{C}$.
Table 1b Course of non-productive infections in corneal cells: keratocytes

\begin{tabular}{|c|c|c|c|c|c|c|}
\hline $\begin{array}{l}\text { Culture } \\
\text { number }\end{array}$ & $\begin{array}{l}\text { Culture } \\
\text { death }\end{array}$ & $\begin{array}{l}\text { No. of } \\
\text { days at } \\
41.5^{\circ} \mathrm{C}\end{array}$ & $\begin{array}{l}\text { Persistent } \\
\text { infection }\end{array}$ & $\begin{array}{l}\text { Latent } \\
\text { infection }\end{array}$ & $\begin{array}{l}\text { Reactiva- } \\
\text { tion failure }\end{array}$ & $\begin{array}{l}\text { Time of virus } \\
\text { release after } \\
\mathrm{HS} \text { removal } \\
\text { at } 37^{\circ} \mathrm{C} \\
\text { (days) }\end{array}$ \\
\hline $1 A^{*} \S$ & & 7 & & + & & 3 \\
\hline 1B & & 7 & & + & & 3 \\
\hline $2 A$ & & 7 & & + & & 3 \\
\hline $2 B$ & & 7 & & + & & 3 \\
\hline $3 A$ & + & 14 & & & & \\
\hline 3B & + & 14 & & & & \\
\hline $4 A$ & + & 14 & & & & \\
\hline 4B & + & 14 & & & & \\
\hline $5 \mathrm{~A}$ & & 21 & & & + & \\
\hline $5 B$ & & 21 & & + & & 6 \\
\hline $6 A$ & & 21 & & & + & \\
\hline $6 B$ & & 21 & & + & & 6 \\
\hline $7 \mathrm{~A}$ & & 28 & & & + & \\
\hline $7 B$ & & 28 & & & + & \\
\hline $8 A$ & & 28 & & & + & \\
\hline $8 B$ & & 28 & & + & & 5 \\
\hline $9 \dagger$ & & 7 & & + & & 6 \\
\hline 10 & & 7 & & + & & 11 \\
\hline 11 & & 14 & & + & & 13 \\
\hline 12 & & 14 & & + & & $2>$ \\
\hline 13 & + & 21 & & & & \\
\hline 14 & + & 21 & & & & \\
\hline 15 & + & 28 & & & & \\
\hline 16 & + & 28 & & & & \\
\hline $17 \ddagger$ & & 7 & & + & & 9 \\
\hline 18 & & 7 & & + & & 23 \\
\hline 19 & & 14 & & + & & 7 \\
\hline 20 & + & 14 & & & & \\
\hline 21 & + & 21 & & & & \\
\hline 22 & & 21 & & + & & $1>$ \\
\hline 23 & & 28 & & + & & $>$ \\
\hline 24 & + & 28 & & & & \\
\hline
\end{tabular}

See footnote to Table 1c.

\section{Discussion}

In man the cornea is a site where recurrent herpetic disease occurs. We have grown separate cultures of rabbit corneal epithelial cells, keratocytes, and endothelial cells whose purity has been defined both morphologically and by cell specific markers. The three cell types have been used initially to study the lytic cycle of HSV-1 in corneal cells and secondly to establish an in-vitro latency system in cells where the virus is known to occur in vivo.

Previous in-vitro latency models have used HEL-F cells and cytosine arabinoside, ${ }^{20}$ rat fetal neurones and BVdUR plus interferon, ${ }^{21}$ and human fetal neurones and BVdUR plus interferon, ${ }^{24}$ to examine virus and cell specific functions related to latency. All these systems employed viral inhibitors. Temperature elevation alone has been shown to induce latent 
Table 1c Course of non-productive infections in corneal cells: endothelium

\begin{tabular}{|c|c|c|c|c|c|c|}
\hline $\begin{array}{l}\text { Culture } \\
\text { number }\end{array}$ & $\begin{array}{l}\text { Culture } \\
\text { death }\end{array}$ & $\begin{array}{l}\text { No. of } \\
\text { days at } \\
41 \cdot 5^{\circ} \mathrm{C}\end{array}$ & $\begin{array}{l}\text { Persistent } \\
\text { infection }\end{array}$ & $\begin{array}{l}\text { Latent } \\
\text { infection }\end{array}$ & $\begin{array}{l}\text { Reactiva- } \\
\text { tion failure }\end{array}$ & $\begin{array}{l}\text { Time of virus } \\
\text { release after } \\
\mathrm{HS} \text { removal } \\
\text { at } 37^{\circ} \mathrm{C} \\
\text { (days) }\end{array}$ \\
\hline $1^{*}$ & & 7 & & + & & 9 \\
\hline $2 A \S$ & & 7 & & + & & 3 \\
\hline $2 B$ & & 7 & & + & & 3 \\
\hline 3 & & 14 & & & + & \\
\hline 4 & & 14 & & + & & 2 \\
\hline 5 & & 21 & & + & & 6 \\
\hline 6 & & 21 & & + & & 9 \\
\hline 7 & & 28 & & + & & 2 \\
\hline 8 & & 28 & & & + & \\
\hline 9A $\dagger$ & & 7 & & + & & 3 \\
\hline $9 B$ & & 7 & & + & & 3 \\
\hline 10 & & 7 & & + & & 3 \\
\hline 11 & $C<$ & 14 & & & & \\
\hline 12 & & 14 & & + & & 2 \\
\hline $13 \mathrm{~A}$ & & 21 & & & + & \\
\hline $13 B$ & $\mathrm{C}$ & 21 & & & & \\
\hline 14 & & 21 & & + & & 3 \\
\hline 15 & & 28 & & + & & 2 \\
\hline $16 \mathrm{~A}$ & + & 28 & & & & \\
\hline 16B & + & 28 & & & & \\
\hline $17 \ddagger$ & $\mathrm{C}$ & 7 & & & & \\
\hline 18 & & 7 & & + & & 9 \\
\hline 19 & & 14 & & + & & 7 \\
\hline 20 & + & 14 & & & & \\
\hline 21 & + & 21 & & & & \\
\hline 22 & & 21 & & + & & 3 \\
\hline 23 & & 28 & & + & & 5 \\
\hline 24 & & 28 & & + & & 2 \\
\hline
\end{tabular}

${ }^{*}$ Cultures 1-8, MOI 0.01 PFU/cell. †Cultures 9-16, MOI 0.1 PFU/cell. ‡Cultures 17-24, MOI 1.0 PFU/cell. §A or B: Cultures were split $1: 2$ on day $13 .<\mathrm{C}$ : Cell death occurred owing to contamination. $>$ Cultures shed virus at $37^{\circ} \mathrm{C}$ in the presence of human serum; keratocyte culture 23 did not shed any other virus at $37^{\circ} \mathrm{C}$.

viral infection in HEL-F cells. ${ }^{26}$ The in-vitro latency system reported here is solely dependent on manipulation of temperature to induce and reactivate latent HSV-1 infections. The in-vitro latency system was used to determine whether peripheral cells, which are a known focus of recurrent disease in man, are capable of supporting latent HSV infection.

The viral growth rate was fastest in epithelial cells and closely resembled that in control BHK $21 \mathrm{C} 13$ cells. The growth rate was intermediate in keratocyte cells and slowest in endothelial cells. Experiments by Carter et al. ${ }^{40}$ using corneal cells infected with HSV at lower MOIs suggested that virus titres reached their maximum in 24 hours and then remained relatively constant until 72 hours. It can be concluded that corneal epithelial, keratocyte, and endothelial cells were capable of efficiently supporting HSV replication.
Our experiments have shown that the three corneal cell types were capable of replication under heat shock conditions (Table 2, column 1). Splitting cultures $1: 2$ at $41.5^{\circ} \mathrm{C}$ did not induce detectable reactivation of infectious virus. In our in-vitro latency system the multiplicity of infection was found to be critical; when $0 \cdot 1,1.0 \mathrm{PFU} /$ cell was used, a very large proportion of cells were killed in the immediate seven days after infection. This effect was overwhelming in some keratocyte and endothelial cell cultures, leaving no surviving cells (Table 2, column 2). The findings were comparable with the results of O'Neill et al. ${ }^{20}$ who found that the innoculating MOI was critical to ensure surviving cells. Wigdahl et al. ${ }^{24}$ have successfully increased the MOI by using a combination of the antiviral drug BVdUR and interferon to treat cells pior to infection with HSV.

Epithelial cells were the only cell type to exhibit persistence, defined as a detectable chronic lowgrade viral infection, insufficient to destroy the cellular monolayer at $41 \cdot 5^{\circ} \mathrm{C}$ (Table 2 , column 3 ). The three corneal cell types could support latent HSV infection, defined by absence of infectious virus in supernatant medium at $41.5^{\circ} \mathrm{C}$ assayed on BHK21 $\mathrm{C} 13$ cells but presence of infectious virus in supernatant medium at $37^{\circ} \mathrm{C}$ assayed on BHK21 C13 cells (Table 2, column 4). Virus was released more quickly from epithelial cells and endothielial cells than from keratocytes at $37^{\circ} \mathrm{C}$ (Table 2, column 6).

Corneal cell types have different properties of replication in vivo, with epithelial cells dividing and being shed throughout life whereas keratocytes have replicative potential but tend to be stable, and endothelial cells have limited if any replicative ability in vivo. ${ }^{30}{ }^{31} \mathrm{It}$ is established that HSV latency occurs in non-dividing neurones in vivo, both in man $^{12}$ and in animals. ${ }^{34}$ Wigdahl et al. ${ }^{41}$ showed in an in-vitro system that neurones were capable of supporting more latent HSV genomes per haploid cell than HEL-F cells. We have shown in our in-vitro system that keratocyte and endothelial cells which are nondividing in vivo are capable of maintaining a latent HSV infection. Epithelial cells are also capable of maintaining an in-vitro latent HSV-1 infection, but in addition epithelial cells showed some persistent HSV infection at $41 \cdot 5^{\circ} \mathrm{C}$. No surviving epithelial cell cultures failed to release infectious $\mathrm{HSV}$ on transfer to $37^{\circ} \mathrm{C}$, in contrast to keratocyte and endothelial cultures, where eight cultures in total did not release infectious virus at $37^{\circ} \mathrm{C}$ (Table 2 , column 5 ). It is possible that non-inducible herpes simplex virus was present in these cultures and might have been detected by viral superinfection experiments.

The mechanismś regulating viral latency are still unclear. In our in-vitro latency system only temperature elevation or reduction has been used to induce 

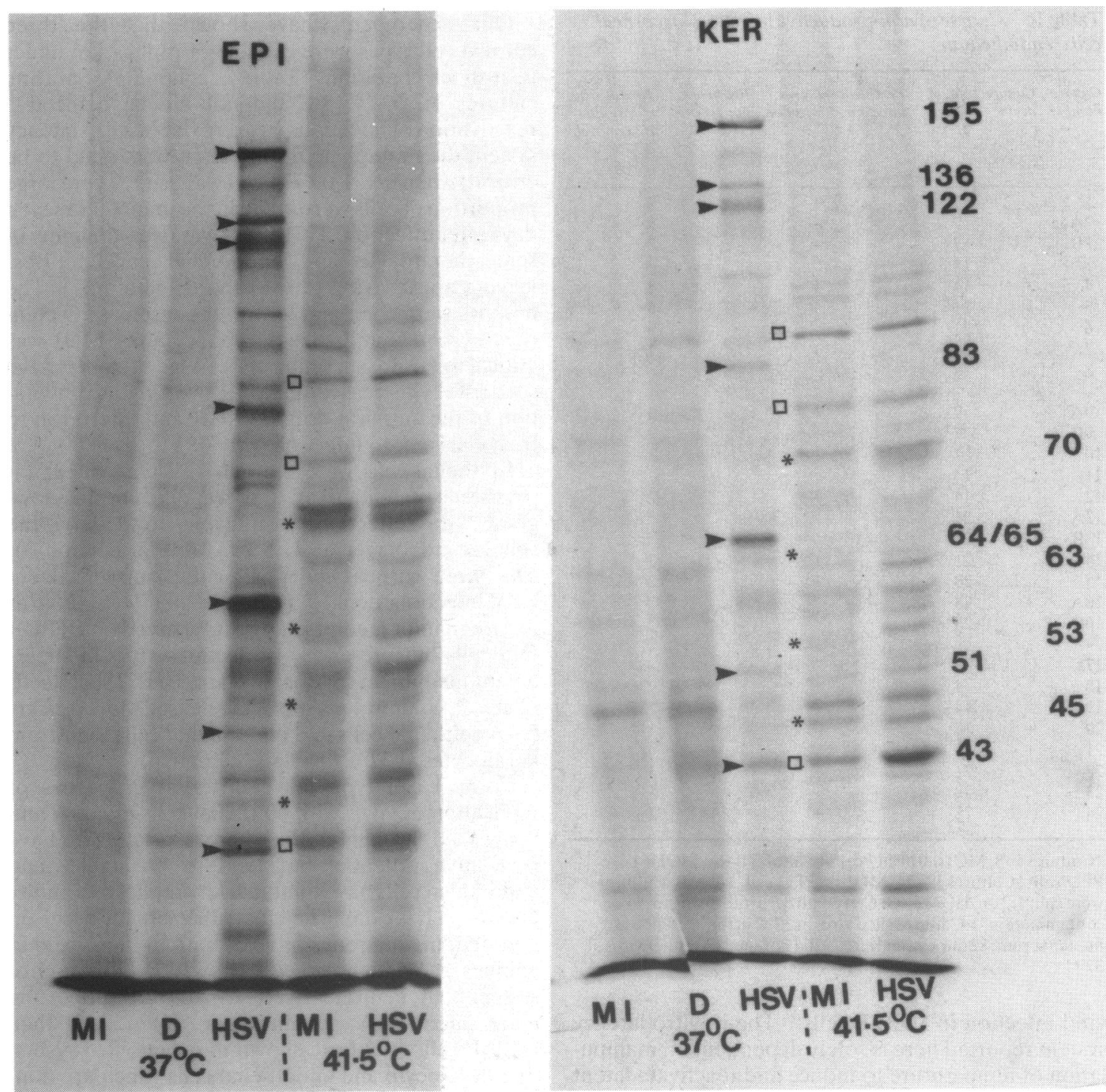

Fig. 2 Protein synthesis in rabbit corneal epithelial cells and keratocytes. Cultures were mock infected (MI), treated with 0.3 $\mu M$ disulfiram (D), or infected with herpes simplex virus at $20 \mathrm{PFU} / \mathrm{cell}(\mathrm{HSV})$. Cultures were maintained at $37^{\circ} \mathrm{C}$ or $41.5^{\circ} \mathrm{C}$. $\square$ Increased synthesis of cellular stress proteins. ${ }^{*}$ Synthesis of novel stress proteins. Synthesis of HSV induced proteins. Approximate molecular weights of HSV proteins are given on the near right of the last track. Approximate molecular weights of stress proteins are given on the far right.

Table 2 Cumulative data of non-productive infections in corneal cells

\begin{tabular}{lllllll}
\hline & $\begin{array}{l}\text { Total no. of cell } \\
\text { cultures }\end{array}$ & $\begin{array}{l}\text { \% Culture death } \\
\text { (including } \\
\text { contamination) }\end{array}$ & $\begin{array}{l}\text { \% persistent } \\
\text { infection }\end{array}$ & $\begin{array}{l}\text { \% Latent } \\
\text { infection }\end{array}$ & $\begin{array}{l}\text { \% Reactivation } \\
\text { failure }\end{array}$ & $\begin{array}{l}\text { Means of virus } \\
\text { release at 37 Cafter } \\
\text { HS removal (days) }\end{array}$ \\
\hline Epithelium & 25 & 4 & 20 & 76 & 0 & 3.6 \\
Keratocytes & 32 & 34 & 0 & 50 & 16 & $6 \cdot 3$ \\
Endothelium & 28 & 25 & 0 & 64 & 11 & $4 \cdot 2$ \\
\hline
\end{tabular}


latency or trigger reactivation. Heat shock induces stress proteins. ${ }^{27}$ Notarianni and Preston ${ }^{28}$ have shown that stress proteins are induced by the immediate early proteins of HSV. In our system most cellular stress proteins were induced by heat shock. It was not possible to ascertain whether additional proteins were induced in any of the three cell types infected at low MOI with HSV. However it is clear that cellular stress proteins were present at $41.5^{\circ} \mathrm{C}$ when HSV is latent and were much reduced in intensity at $37^{\circ} \mathrm{C}$ when virus was able to reactivate. This virus/cell interaction may well have a role in the control of viral latency.

The study of latency in separated corneal cells promises to be of value in the understanding of problems posed in herpes simplex virus keratitis. Our results support the hypothesis that non-neural cells are capable of maintaining latent $\mathrm{HSV}$ infection.

We are grateful to Professors J H Subak-Sharpe and W S Foulds for critical reading of this paper, and to Mrs $J$ Mavor for typing the manuscript. Dr S D Cook is supported by a Medical Research Council Training Fellowship.

\section{References}

1 Bastian FO, Rabson AS, Yee CL, Tralka TS. Herpesvirus hominis: isolation from human trigeminal ganglions. Science 1972; 178: 306-7.

2 Baringer JR, Swoveland P. Recovery of herpes simplex virus from trigeminal ganglions. N Engl J Med 1973; 288: 648-50.

3 Stevens JG, Cook ML. Latent herpes simplex virus in spinal ganglia of mice. Science $1971 ; 273$ : 843-5.

4 Stevens JG, Nesburn AB, Cook ML. Latent herpes simplex virus from trigeminal ganglia of rabbits with recurrent eye infection. Nature 1972; 235: 216-7.

5 Wildy P, Field HJ, Nash AA. Classical herpes latency revisited. Society for General Microbiology Symposium 1982; 33: 13368.

6 Hill TJ, Blyth WA, Harbour DA. Recurrence of herpes simplex in the mouse requires an intact nerve supply. J Gen Virol 1983; 64: $2763-5$.

7 Scriba M, Tatzber F. Pathogenesis of herpes simplex virus infections in guinea pigs. Infect Immun 1981; 34: 655-61.

8 Al-Saadi SA, Clements GB, Subak-Sharpe JH. Viral genes modify herpes simplex virus latency both in mouse footpad and sensory ganglia. J Gen Virol 1983; 64: 1175-9.

9 Openshaw HR. Latency of herpes simplex virus in ocular tissue of mice. Infect Immun 1983; 39: 960-2.

10 Nesburn AB, Elliott JH, Leibowitz HM. Spontaneous reactivation of experimental herpes simplex keratitis in rabbits. Arch Ophthalmol 1967; 78: 523-9.

11 Hill TJ, Field HJ, Blyth WA. Acute and recurrent infection with herpes simplex virus in the mouse: a model for studying latency and recurrent disease. J Gen Virol 1975; 28: 341-53.

12 Coleman VR, Thygeson P, Dawson CR, Jawetz E. Isolation of virus from herpetic keratitis. Arch Ophthalmol 1969; 81: 224.

13 Kaufman HE. Herpetic stromal disease. Am J Ophthalmol 1975; 80: $1092-4$.

14 Vannas A, Ahonen R, Mäkitie J. Corneal endothelium in herpetic keratouveitis. Arch Ophthalmol 1983; 101: 913-5.

15 Dawson C, Togni B, Moore TE. Structural changes in chronic herpetic keratitis. Arch Ophthalmol 1968; 79: 740-7.

16 Metcalf JF, Kaufman HE. Herpetic stromal keratitis-evidence for cell mediated immunopathogenesis. Am J Ophthalmol 1976; 82: 827-34.

17 Meyers-Elliott RH, Chitjian PA. Induction of cell mediated immunity in herpes simplex virus keratitis. Invest Ophthalmol Vis Sci 1980; 19: 920-9.

18 Shimeld C, Tullo AB, Easty DL, Thomsitt J. Isolation of herpes simplex virus from the cornea in chronic stromal keratitis. $B r J$ Ophthalmol 1982; 66: 643-7.

19 Tullo AB, Easty DL, Shimeld C, Stirling PE, Darville JM. Isolation of herpes simplex virus from corneal discs of patients with chronic stromal keratitis. Trans Ophthalmol Soc UK 1985; 104: 159-65.

20 O'Neill FJ, Goldberg RJ, Rapp F. Herpes simplex virus latency in cultured human cells following treatment with cytosine arabinoside. J Gen Virol 1972; 14: 189-97.

21 Wigdahl BL, Ziegler RJ, Sneve M, Rapp F. Herpes simplex virus latency and reactivation in isolated rat sensory neurones. Virology 1983; 127: 159-67.

22 Wigdahl BL, Smith CA, Traglia HM, Rapp F. Herpes simplex virus latency in isolated human neurones. Proc Natl Acad Sci USA 1984; 81: 6217-21.

23 Adler R, Glorioso JC, Levine M. Infection by herpes simplex virus and cells of nervous system origin: characterization of a non-permissive interaction. J Gen Virol 1978; 39: 9-20.

24 Wigdahl BL, Scheck AC, De Clerq ED, Rapp F. High efficiency latency and activation of herpes simplex virus in human cells. Science 1982; 217: 1145-6.

25 O'Neill FJ. Prolongation of herpes simplex virus latency in cultured human cells by temperature elevation. J Virol 1977; 24: 41-6.

26 Russeli J, Preston CM. An in vitro latency system for herpes simplex virus type 2. J Gen Virol 1986; 67: 397-403.

27 Tissieres A, Mitchell HK, Tracy UM. Protein synthesis in salivary glands of Drosophila melanogaster: relation to chromosome puffs. J Mol Biol 1974; 84: 389-98.

28 Notarianni EL, Preston CM. Activation of cellular stress protein genes by herpes simplex virus temperature-sensitive mutants which overproduce immediate early polypeptides. Virology 1982; 123: 113-22.

29 Colberg-Poley AM, Isom H, Rapp F. Reactivation of herpes simplex virus type 2 from a quiescent state by human cytomegalovirus. Proc Natl Acad Sci USA 1979; 76: 5948-51.

30 Davson H. Physiology of the eye. London and Edinburgh: Churchill Livingstone, 1980: 89-94.

31 Maumenee $\mathrm{AE}$, Kornblueth $\mathrm{W}$. Regeneration of corneal stromal cells. Am J Ophthalmol 1949; 32: 1051-64.

32 Brown SM, Ritchie DA, Subak-Sharpe JH. Genetic studies with herpes simplex virus type 1 . The isolation of temperaturesensitive mutants, their arrangement into complementation groups and recombination analysis leading to a linkage map. $J$ Gen Virol 1973; 18: 329-46.

33 Stocker FW, Eiring A, Georgiade, R, Georgiade N. A tissue culture technique for growing corneal epithelial, stromal, and endothelial tissues separately. Am J Ophthalmol 1958; 46: 294-8.

34 Marsden HS, Crombie IK, Subak-Sharpe JH. Control of protein synthesis in herpesvirus-infected cells: analysis of the polypeptides induced by wild type and sixteen temperature sensitive mutants of HSV strain 17. J Gen Virol 1976; 31: 347-72.

35 Yamada KM, Olden K. Fibronectins - adhesive glycoproteins on cell surface and blood. Nature 1978; 275: 179-84.

36 Gospodarowicz D, Greenburg G, Vlodavsky I, Alvardo J, Johnson LK. The identification and localization of fibronectin in cultured endothelial cells: cell surface polarity and physiological implications. Exp Eye Res 1979; 29: 485-509.

37 Lazarides E. Intermediate filaments as mechanical integrators of cellular space. Nature 1980; 283 : 249-56.

38 Levinson W, Oppermann H, Jackson J. Transition series metals and sulphydryl reagents induce the synthesis of four proteins in eukaryotic cells. Biochim Biophys Acta 1980; 606: 170-80. 
39 Levinson W, Mikelens P, Oppermann H, Jackson J. Effect of Antabuse (disulfiram) on Rous sarcoma virus and on eukaryotic cells. Biochim Biophys Acta 1978; 519: 65-75.

40 Carter C, Dyson H, Easty DL. Herpes simplex virus infection of corneal cells in vitro. In: Maudgal PC, Missotten L, eds. Herpetic eye diseases. The Hague: Dr W Junk, 1985: 9-14.
41 Wigdahl B, Scheck AC, Ziegler RJ, De Clerq E, Rapp F. Analysis of the herpes simplex virus genome during in vitro latency in human diploid fibroblasts and rat sensory neurones. $J$ Virol 1984; 49: 205-13.

Accepted for publication 16 January 1986. 